\title{
Pengaruh Kepemilikan Keluarga dan Efektivitas Dewan Komisaris terhadap nilai perusahaan yang tergabung dalam LQ 45 tahun 2012-2013
}

\author{
Apri Dwi Astuti \\ Unswagati Cirebon \\ apri_dwiastuti@yahoo.co.id \\ Arinal Muna \\ Unswagati Cirebon \\ arinalmunaaa@gmail.com
}

\begin{abstract}
The purpose of this study was to examine and analyze family ownership and board of director effectively to the firms value. This study used 30 firms as a sample is consistently listed on LQ 45 in Indonesia Stock Exchange during 2012-2014. This research aimed to examine the effect of ownership stucture and management structure on firm value.

Ownership structure was reflected by family ownership. Management structure was reflected by board of director effectively. Firm value was reflected by the stock price. The sample was determined by using purposive sampling. Analysis of data in this study used SPSS.The result showed that family had effect on firm value. Board of director effectively had effect on firm value.
\end{abstract}

Kata Kunci: family ownership, board of director effectively and firm value

\section{PENDAHULUAN}

Tujuan didirikannya suatu perusahaan adalah untuk memberikan keuntungan bagi pemiliknya yaitu pemegang saham. Salah satu bentuk keuntungan tersebut dapat dilihat dari nilai saham perusahaan yang bersangkutan. Nilai saham suatu perusahaan mencerminkan nilai dari perusahaan tersebut. Retno (2012) mengungkapkan bahwa peningkatan nilai perusahaan yang berkesinambungan adalah tujuan jangka panjang dari perusahaan untuk memaksimalisasi nilai pemegang Berdasarkan hukum permintaan dan penawaran, harga saham yang merupakan cerminan dari nilai pasar perusahaan ditentukan oleh minat dari para investor untuk membeli atau saham. Hal ini senada dengan Wang (2011) yang juga menyatakan bahwa peningkatan nilai perusahaan merupakan cerminan dari optimalisasi kekayaan pemegang saham, yang sering dinilai dengan Price to Book Value $(P B V)$ karena dengan rasio ini memperlihatkan kemauan investor untuk membeli saham dengan harga di atas atau di bawah nilai nominal yang juga merupakan cerminan dari penawaran dan permintaan akan surat bukti kepemilikan tersebut.

menjual saham perusahaan. Salah satu faktor yang mempengaruhi menentukan pilihan ini adalah kepastian kelangsungan hidup perusahaan dan tingkat pengembalian dari dana yang 
sudah diinvestasikan. Investor tentunya akan memilih investasi dengan return yang lebih tinggi dan tingkat risiko yang sama, atau memilih return yang sama dengan tingkat risiko yang lebih rendah. Semakin tinggi nilai perusahaan akan semakin sejahtera pemiliknya.

$$
\text { Husnan (2006) menyatakan }
$$

bahwa bagi perusahaan yang berbentuk perseroan terbatas (lebih-lebih yang terdaftar di pasar modal), seringkali terjadi pemisahaan antara pengelola perusahaan (pihak manajemen, disebut juga sebagai agent) dengan pemilik perusahaan (pemegang saham, yang juga disebut sebagai principal) adanya pemisahan antara pemilik perusahaan dengan pengelola perusahaan akan menimbulkan perbedaan kepentingan diantara keduanya yang disebut dengan agency problem. Hal ini didukung oleh Jensen \& Meckling (1976) dalam teori keagenan menyebutkan bahwa ketika perusahaan memisahkan antara fungsi kepemilikan dengan fungsi pengelolaan perusahaan maka akan menimbulkan konflik kepentingan. Adanya perbedaan kepentingan antara pemilik perusahaan dan pengelola perusahaan, dibutuhkan tata kelola yang baik untuk menjembatani konflik kepentingan yaitu corporate governance. Corporate governance merupakan proses dan struktur yang untuk digunakan untuk mengarahkan dan mengelola bisnis serta urusan-urusan perusahaan, dalam rangka meningkatkan kemakmuran dan akuntabilitas perusahaan, dengan tujuan utama mewujudkan nilai pemegang saham dalam jangka panjang dengan tetap memperhatikan kepentingan stakeholders yang lain. Debby et al (2014) menyatakan bahwa sistem tata kepemilikan asing, dan struktur kepemilikan pemerintah.

Di Indonesia kebanyakan perusahaan dimiliki oleh keluarga. Berdasarkan penelitian yang dilakukan kelola perusahaan membantu untuk menciptakan hubungan yang kondusif antara unsur-unsur yang bertanggung jawab di perusahaan (dewan komisaris, direksi dan pemegang saham) dalam rangka meningkatkan nilai perusahaan. Dengan adanya mekanisme corporate governance akan menciptakan pengendalian perusahaan yang baik sehingga agency problem dapat diminimalisir sehingga kinerja perusahaan akan meningkat. Penjelasan di

mengindikasikan

atas pentingnya mekanisme corporate governance terhadap kinerja keuangan dan nilai perusahaan. Gray \& Radebaugh (2009) dalam Bukhori \& Raharja (2012) Mekanisme corporate governance sendiri dibedakan menjadi menjadi 2 (dua) yaitu mekanisme internal dan mekanisme eksternal. Mekanisme internal merupakan cara untuk mengendalikan perusahaan dengan menggunakan struktur dan proses internal yang terdiri dari struktur kepemilikan dan struktur pengelolaan. Mekanisme eksternal merupakan cara mempengaruhi perusahaan selain dengan menggunakan mekanisme internal yang terdiri dari pihak-pihak yang berasal dari luar perusahaan seperti pasar modal, pasar uang, regulator dan undang-undang.

Salah satu mekanisme internal dari corporate governance adalah struktur kepemilikan dan struktur pengelolaan. Struktur kepemilikan sendiri terbagi menjadi beberapa struktur diantaranya adalah struktur kepemilikan keluarga, struktur kepemilikan institusional, struktur kepemilikan manajerial, struktur oleh Claessens et al.(2000b) lebih dari dua per tiga perusahaan di Indonesia dimiliki oleh sejumlah anggota keluarga. Oleh karena itu, dalam penelitian ini akan di fokuskan pada 
struktur kepemilikan keluarga. Disisi lain, Struktur pengelolaan perusahaan dalam penelitian ini di fokuskan kepada efektivitas dari dewan komisaris. Dewan komisaris bertugas untuk melakukan pengawasan atas kebijakan pengurus, jalannya kepengurusan dan memberikan nasehat kepada dewan direksi. Dengan wewenang pengawasan oleh dewan komisaris akan memastikan terciptanya akuntabilitas dalam manajemen perusahaan.

Bursa efek indonesia memiliki berbagai indeks, salah satunya adalah indeks liquid 45 (LQ 45). Menurut Hartono dalam khairiyani (2016) menyatakan bahwa indeks LQ 45 dibentuk hanyadari 45 saham-saham yang paling aktif diperdagangkan. Penelitian ini berfokus pada perusahaan LQ 45. Perusahaan LQ 45 adalah perusahaan go public yang terdaftar pada bursa efek Indonesia.

\section{KAJIAN LITERATUR \\ Teori agensi}

Teori ini dikemukakan oleh Michael C. Jensen dan William $\mathrm{H}$. Meckling (1976) yang menjelaskan hubungan keagenan sebagai:

"agency relationship as a contract under which one or more person (the principals) engage another person (the agent) to perform some service on their behalf which involves delegating some decision making authority to the agent".

Teori agensi merupakan konsep yang menjelaskan hubungan kontraktual antara principal dan agents. Pihak

\section{Corporate Governance}

Monks dan minow (2004) menempatkan corporate governance sebagai upaya untuk menjaga hubungan antara tiga faktor penting dalam setiap korporasi yaitu pemilik, manajemen dan
Berdasarkan latar belakang diatas, penelitian ini berfokus pada mekanisme internal dari corporate governance dimana struktur kepemilikan yang digunakan adalah kepemilikan keluarga dan struktur pengelolaan perusahaan menggunakan efektivitas dewan komisaris. Perbedaan penelitian ini dengan penelitian sebelumnya yang pernah dilakukan oleh khairiyani (2016) terletak pada penggunaan kepemilikan keluarga dan efektivitas dewan komisaris.

Berdasarkan latar belakang diatas diperoleh rumusan masalah dalam penelitian ini adalah apakah struktur kepemilikan keluarga dan efektivitas dewan komisaris berpengaruh terhadap nilai perusahaan?

Tujuan dari penelitian ini adalah untuk membuktikan secara empiris pengaruh struktur kepemilikan keluarga dan efektivitas dewan komisaris terhadap nilai perusahaan

principal adalah adalah pihak yang memberikan mandat kepada pihak lain, yaitu agent, untuk melakukan semua kegiatan atas nama principal dalam kapasitasnya sebagai pengambil keputusan. Teori keagenan mendeskripsikan hubungan antara pemegang saham (shareholders) sebagai prinsipal dan manajemen sebagai agen. Manajemen merupakan pihak yang dikontrak oleh pemegang saham untuk bekerja demi kepentingan pemegang saham, sehingga pihak manejemen harus mempertanggungjawabkan semua pekerjaannya kepada pemegang saham.

BOD (atau dewan komisaris di Indonesia). Definisi ini mengisyaratkan bahwa dengan berjalannya hubungan yang harmonis sesuai dengan domain masing-masing aktor utama di setiap korporasi, akan menjamin berjalannya 
mekanisme pengendalian korporasi secara optimal sesuai dengan tujuan corporate governance.

\section{Mekanisme Corporate Governance}

Shleifer dan Vishny (1997), menyatakan bahwa governance mechanism dibutuhkan sebagai bagian penting dalam kerangka corporate governance karena dapat memberikan jaminan bahwa setiap investor dapat memperoleh pengembalian dari setiap investasi yang dilakukannya. Mekanisme governance dapat diaktegorikan secara umum berdasarkan karakteristiknya sebagai bagian internal atau eksternal dari sebuah korporasi. Perhatian utama terhadap mekanisme internal dari suatu sistem governance adalah pada keberadaan dan peranan board of director (dewan komisaris di Indonesia). Penelitian ini menggunakan mekanisme internal yaitu struktur kepemilikan keluarga dan struktur pengelolaan yaitu efektivitas dewan komisaris.

\section{PERUMUSAN HIPOTESIS}

\section{Pengaruh struktur kepemilikan keluarga terhadap nilai perusahaan}

Sebagian besar perusahaan publik di Indonesia dimiliki oleh keluarga. Anderson dan Reeb (2003) menyatakan bahwa perusahaan keluarga adalah setiap perusahaan yang memiliki pemegang saham dominan. Sebagai pemilik utama perusahaan, keluarga dapat ikut mengelola perusahaan dan melakukan pengawasan yang maksimal. Dengan pengawasan dan kontrol yang maksimal akan meningkatkatkan kinerja perusahaan. Adanya tanggngjawab oleh pemilik yaitu keluarga maka keputusan yang diambil akan ditujukan untuk meningkatkan nilai perusahaan.

H1 : Struktur kepemilikan keluarga berpengaruh terhadap nilai perusahaan

\section{Pengaruh efektivitas dewan komisaris terhadap nilai perusahaan}

Debby et al (2014) menyatakan bahwa sistem tata kelola perusahaan membantu untuk

menciptakan hubungan yang kondusif antara unsur-unsur yang bertanggungjawab di perusahaan (dewan komisaris, direksi dan pemegang saham) dalam rangka meningkatkan nilai perusahaan. Puteri dan rohmandan, dan sadasiha \& hadiprajitno serta Hariati \& Rihatiningtyas dalam khairiyani (2016) menunjukkan bahwa proporsi dewan komisaris independen berpengaruh terhdapa nilai perusahaan, sedangkan Debby et al (2014) menunjukkan bahwa proporsi dewan komisaris independen tidak berpengaruh terhadap nilai perusahaan.

H2 : Efektivitas dewan komisaris berpengaruh terhadap nilai perusahaan

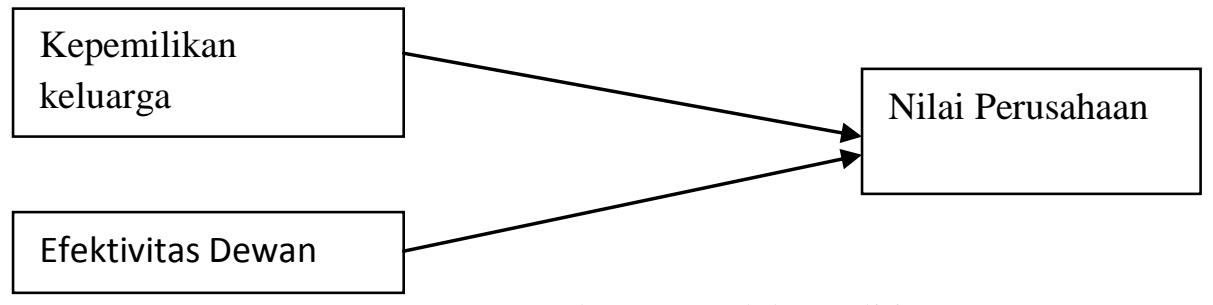

Gambar 1 : model penelitian

\section{Metode Penelitian}

\section{Populasi dan Sampel}

Populasi dalam penelitian ini adalah perusahaan Liquid 45 (LQ 45) yang

Tabel 1. Proses Purposive sampling terdaftar di bursa efek Indonesia tahun 2012-2013. Pemilihan sampel menggunakan metode purposive sampling. 


\begin{tabular}{|l|l|l|}
\hline No & Purposive sampling & jumlah \\
\hline 1 & Perusahaan yang tergabung dalam indeks LQ 45 2012-2013 & 45 \\
\hline 2 & Dikurangi perusahaan yang tidak konsisten dalam indeks LQ 45 & $(15)$ \\
\hline \multicolumn{2}{|c|}{ Jumlah } & 30 \\
\hline
\end{tabular}

\section{Metode pengumpulan data}

Pengumpulan data melalui studi kepustakaan dan referensi lainnya yang mendukung selanjutnya peneliti mengumpulkan data-data perusahaan yang terbit dalam indeks LQ 45 tahun 2012-2013

\section{Pengukuran Variabel}

Penelitian ini menggunakan variabel independen yaitu kepemilikan keluarga (FIRM) dan efektivitas dewan komisaris (EFCOM). Kepemilikan keluarga menggunakan definisi dari penelitian Arifin (2003) yaitu keluarga adalah seluruh individu dan perusahaan yang kepemilikannya tercatat (kepemilikan $5 \%$ ke atas wajib dicatat), kecuali perusahaan publik, negara, institusi keuangan dan publik. Sedangkan efektivitas dewan komisaris dilakukan scoring secara manual. Skor efektivitas dihitung berdasarkan nilai yang diperoleh dari daftar pertanyaan (checklist). Checklist sama yang digunakan oleh Hermawan dalam fitri (2012). Metode penetapan nilai terdiri dari tiga kemungkinan yaitu good, fair dan poor. Good bernilai 3, fair bernilai 2 dan poor bernilai 1. Penelitian ini menggunakan 17 pertanyaan. Oleh katena itu peneliti menggunakan batasan 34 untuk mengkonversikan total skor dewan komisaris menjadi variabel dummy. Untuk nilai perusahaan dalam penelitian ini menggunakan harga saham penutupan per 31 desember sesuai dengan penelitian Mahendra (2011).

\section{Analisis Regresi Berganda.}

Persamaan regresi yang digunakan adalah sebagai berikut

$$
\begin{aligned}
& Y=a+b 1 X 1+b 2 X 2+e \\
& \text { Keterangan : } \\
& Y=\text { Nilai perusahaan } \\
& X 1=\text { kepemilikan Keluarga } \\
& X 2=\text { Efektivitas dewan komisaris }
\end{aligned}
$$

\section{Uji Asumsi Klasik}

Sebelum melakukan uji regresi linier berganda, perlu dilakukan uji asumsi klasik terlebih dahulu.

1. Uji normalitas

Menurut Ghozali (2013) uji normalitas bertujuan untuk menguji apakah dalam model regresi variabel penganggu atau residual memiliki distribusi normal.

2. Uji multikolinieritas

Bertujuan untuk menguji apakah model regresi ditemukan adanya korelasi antar variabel bebas (independen). Model regresi yang baik seharusnya tidak terjadi korelasi di antara variabel independen.

3. Uji Autokorelasi

Bertujuan menguji apakah dalam model regresi linier ada korelasi antara kesalahan penganggu pada periode $t$ dengan kesalahan penganggu pada periode $t$ sebelumnya.

a. Uji Durbin-Watson

Hanya digunakan untuk autokorelasi tingkat satu dan mensyaratkan adanya 
konstanta dalam model regresi dan tidak ada variabel lag diantara variabel independen. Hipotesis yang akan diujikan adalah

H0 : Tidak ada autokorelasi

HA : ada autokorelasi

Tabel 2

Interval Durbin Watson

\begin{tabular}{|l|l|l|}
\hline Hipotesis nol & keputusan & Jika \\
\hline $\begin{array}{l}\text { Tidak ada } \\
\text { autokorelasi } \\
\text { positif }\end{array}$ & Tolak & $\begin{array}{l}0<\mathrm{d} \\
<\mathrm{dl}\end{array}$ \\
\hline $\begin{array}{l}\text { Tidak ada } \\
\text { autokorelasi } \\
\text { positif }\end{array}$ & $\begin{array}{l}\text { No } \\
\text { desicion }\end{array}$ & $\begin{array}{l}\mathrm{dl} \\
\leq \mathrm{d} \leq \mathrm{du}\end{array}$ \\
\hline $\begin{array}{l}\text { Tidak ada } \\
\text { korelasi negatif }\end{array}$ & tolak & $\begin{array}{l}\text { 4-dl }< \\
\mathrm{d}<4\end{array}$ \\
\hline $\begin{array}{l}\text { Tidak ada } \\
\text { korelasi negatif }\end{array}$ & $\begin{array}{l}\text { No } \\
\text { desicion }\end{array}$ & $\begin{array}{l}4-\mathrm{du} \\
\leq \mathrm{d} \leq\end{array}$ \\
\hline
\end{tabular}

\section{HASIL PENELITIAN}

Statistk Deskriptif

Statistik deskriptif memberikan gambaran atau deskriptif suatu data

\begin{tabular}{|l|l|l|}
\hline & & 4-dl \\
\hline Tidak & Tidak & $\mathrm{Du}<$ \\
$\begin{array}{l}\text { autokorelasi } \\
\text { positif atau } \\
\text { negatif }\end{array}$ & ditolak & $\mathrm{d}<4-$ \\
\hline
\end{tabular}

4. Uji heteroskedastisitas

Bertujuan menguji apakah dalam model terjadi ketidaksamaan variance dari residual satu pengamatan ke pengamatan yang lain. Ada beberapa cara untuk mendeteksi ada atau tidaknya heteroskedastisitas yaitu dengan melihat grafik plot. yang dilihat dari nilai rata-rata, standar deviasi, varian, maksimum, minimum, sum, range, kurtosis dan skewness.

Tabel 3

Statistik Deskriptif

Descriptive Statistics

\begin{tabular}{|l|r|r|r|r|r|}
\hline & $\mathrm{N}$ & Minimum & Maximum & Mean & Std. Deviation \\
\hline X1 & 60 &, 0000 &, 8500 &, 240115 &, 3113890 \\
X2 & 60 &, 0 & 1,0 &, 867 &, 3428 \\
Y & 60 & 100,0 & 60450,0 & 9795,167 & 11557,7608 \\
Valid N (listwise) & 60 & & & & \\
\hline
\end{tabular}

Sumber : output SPSS 22

Output tampilan SPSS menunjukkan jumlah responden $(\mathrm{N})$ ada 60 dengan kepemilikan keluarga (X1) minimum 0,0000 dan maksimum 0,8500 . Untuk efektivitas dewan komisaris (X2) minimum adalah 0 dan maksimum bernilai 1 sedangkan untuk nilai perusahaan (Y) minimum 100 dan maksimum 60.450. rata-rata untuk kepemilikan keluarga dalah 0,24011, untuk kepemilikan keluarga adalah 0,867 sedangkan nilai perusahaan memiliki rata-rata 9795. 


\section{Uji normalitas}

Tabel 4

Uji Normalitas

One-Sample Kolmogorov-Smirnov Test

\begin{tabular}{|ll|r|}
\hline & & $\begin{array}{r}\text { Unstandardized } \\
\text { Residual }\end{array}$ \\
\hline $\mathrm{N}$ & Mean & 60 \\
Normal Parameters ${ }^{\mathrm{a}, \mathrm{b}}$ & Std. Deviation &, 0000000 \\
& Absolute & 9869,86052489 \\
Most Extreme Differences & Positive &, 099 \\
& Negative &, 099 \\
& &,- 081 \\
Test Statistic &, 099 \\
Asymp. Sig. (2-tailed) & &, $200^{\mathrm{c}, \mathrm{d}}$ \\
\hline
\end{tabular}

a. Test distribution is Normal.

b. Calculated from data.

Sumber : hasil outpus SPSS 22

Berdasarkan output SPSS nilai signifikan adalah0,200 lebih besar dari 0,005 berarti data berdistribusi normal.

\subsection{Uji Multikolinieritas}

Tabel 5

Uji Multikolinieritas

Coefficients $^{a}$

\begin{tabular}{|c|c|c|c|c|c|c|c|c|}
\hline \multirow{2}{*}{\multicolumn{2}{|c|}{ Model }} & \multicolumn{2}{|c|}{$\begin{array}{c}\text { Unstandardized } \\
\text { Coefficients }\end{array}$} & \multirow{2}{*}{$\begin{array}{c}\begin{array}{c}\text { Standardized } \\
\text { Coefficients }\end{array} \\
\text { Beta } \\
\end{array}$} & \multirow[b]{2}{*}{$\mathrm{T}$} & \multirow[b]{2}{*}{ Sig. } & \multicolumn{2}{|c|}{$\begin{array}{c}\text { Collinearity } \\
\text { Statistics }\end{array}$} \\
\hline & & $\mathrm{B}$ & Std. Error & & & & Tolerance & VIF \\
\hline \multirow[t]{3}{*}{1} & (Constant) & 18163,945 & 4167,746 & & 4,358 & ,000 & & \\
\hline & $\mathrm{X} 1$ & 9951,639 & 4432,315 & ,268 & 2,245 & ,029 & ,897 & 1,115 \\
\hline & $\mathrm{x} 2$ & $-12413,442$ & 4026,139 &,- 368 & $-3,083$ & ,003 & ,897 & 1,115 \\
\hline
\end{tabular}

a. Dependent Variable: y

Sumber : hasil output SPSS 22

Berdasarkan hasil SPSS nilainya lebih dari 95\%. Hasil menunjukkan tidak ada variabel perhitungan nilai VIF juga independen yang memiliki nilai menunjukkan hal yang sama tidak ada Tolerance kurang dari 0,10 yang berarti satu variabel independen yang memiliki tidak ada korelasi antar variabel yang nilai VIF lebih dari 10. 


\section{Uji Autokorelasi}

Tabel 6

Uji Autokorelasi

\begin{tabular}{|l|r|r|r|r|r|}
\hline \multicolumn{1}{|c|}{ Model $^{\text {Model Summary }}$} \\
\hline 1 & $\mathrm{R}$ & R Square & $\begin{array}{c}\text { Adjusted R } \\
\text { Square }\end{array}$ & $\begin{array}{c}\text { Std. Error of the } \\
\text { Estimate }\end{array}$ & Durbin-Watson \\
\hline
\end{tabular}

a. Predictors: (Constant), X2, X1

b. Dependent Variable: y

Sumber : hasil output SPSS

Oleh karena nilai DW 1.883 lebih besar dari batas (du) 1.689 dan kurang dari 4-

1.689 (4-du), maka dapat disimpulkan bahwa tidak ada autokorelasi.

\section{Uji Heteroskedastisitas}

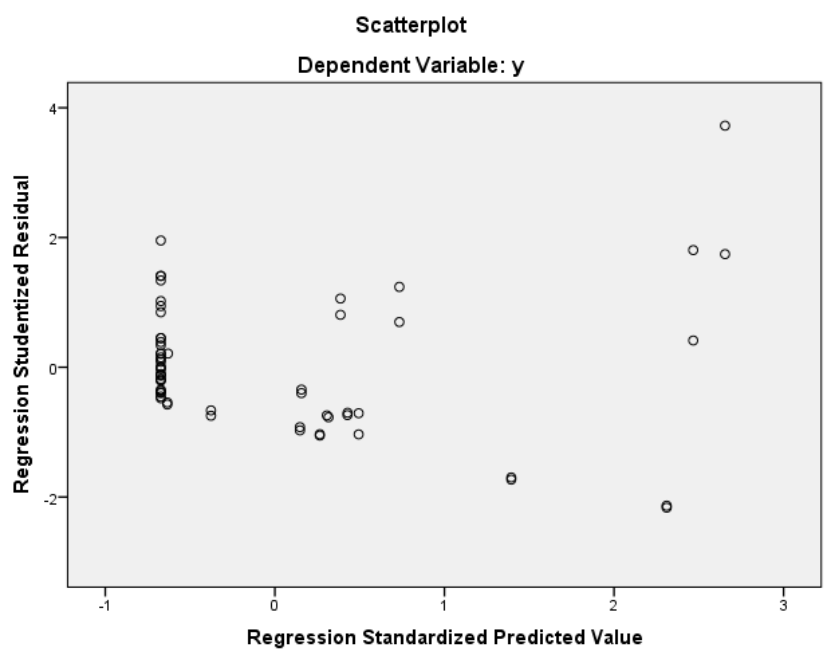

Sumber : hasil output SPSS 22

Berdasarkan gambar Scatterplot dapat dilihat titik-titik menyebar. Titiktitik menyebar diatas dan dibawah angka 0 serta penyebaran titik-titik data

tersebut tidak berpola sehingga menunjukkan bahwa data penelitian ini tidak terjadi masalah heteroskedastisitas.

\section{Analisis Regresi}

Metode analisis data yang digunakan dalam penelitian ini adalah metode analisis regresi linier berganda. Model analisis ini digunakan untuk

4.1.1 Analisis Regresi berganda Tabel 7 hasil uji Regresi berganda

mengetahui apakah variabel independen kepemilikan keluarga (X1), efektivitas dewan komisaris (X2) berpengaruh terhadap variabel dependen nilai perusahaan $(\mathrm{Y})$.

Model Summary ${ }^{\text {b }}$

\begin{tabular}{|l|r|r|r|r|r|}
\hline Model & $\mathrm{R}$ & R Square & \multicolumn{1}{c|}{$\begin{array}{c}\text { Adjusted R } \\
\text { Square }\end{array}$} & $\begin{array}{c}\text { Std. Error of the } \\
\text { Estimate }\end{array}$ & Durbin-Watson \\
\hline 1 &, $520^{\mathrm{a}}$ &, 271 &, 245 & 10041,5231 & 1,883 \\
\hline
\end{tabular}


a. Predictors: (Constant), X2, X1

b. Dependent Variable: $y$

Sumber : hasil outpus SPSS 22

Berdasarkan output diatas dapat dilihat pengaruh kepemilikan keluarga dan efektivitas dewan komisaris yang ditunjukkan pada nilai R Square sebesar 0,271 atau $27,1 \%$. Hal ini berarti bahwa

\subsubsection{Uji t}

Uji t pada dasarnya menunjukkan seberapa jauh pengaruh satu variabel independen secara parsial

Tabel 8 Uji t secara bersama-sama pengaruh kepemilikan keluarga dan efektivitas dewan komisaris terhadap nilai perusahaan $27 \%$ sisanya $73 \%$ dipengaruhi faktor lainnya.

dalam menerangkan variabel dependen.

Coefficients $^{\mathrm{a}}$

\begin{tabular}{|c|c|c|c|c|c|c|}
\hline \multirow{2}{*}{\multicolumn{2}{|c|}{ Model }} & \multicolumn{2}{|c|}{ Unstandardized Coefficients } & \multirow{2}{*}{$\begin{array}{l}\text { Standardized } \\
\text { Coefficients } \\
\text { Beta }\end{array}$} & \multirow[b]{2}{*}{$\mathrm{t}$} & \multirow[b]{2}{*}{ Sig. } \\
\hline & & B & Std. Error & & & \\
\hline \multirow[t]{3}{*}{1} & (Constant) & 18163,945 & 4167,746 & & 4,358 & ,000 \\
\hline & $\mathrm{X} 1$ & 9951,639 & 4432,315 & ,268 & 2,245 & ,029 \\
\hline & $\mathrm{X} 2$ & $-12413,442$ & 4026,139 &,- 368 & $-3,083$ &, 003 \\
\hline
\end{tabular}

a. Dependent Variable: $y$

Berdasarkan hasil SPSS diketahui bahwa kepemilikan keluarga (X1) signifikan karena 0,029 lebih kecil dibandingkan nilai signifikan 0,05 sedangkan efektivitas dewan komisaris signifikan pada nilai 0,003 lebih kecil dibandingkan 0,05. Persamaan yang diperoleh dari hasil diatas adalah

$$
\mathrm{Y}=18.163+\text { 9951FIRM - }
$$$$
\text { 12.413EFCOM + e }
$$

\subsubsection{Uji F}

Tabel 9 hasil uji $\mathrm{F}$

\begin{tabular}{|ll|r|r|r|r|r|}
\hline Model & & Sum of Squares & Df & Mean Square & F & Sig. \\
\hline 1 & Regression & 2133893588,269 & 2 & 1066946794,134 & 10,581 &, $000^{\mathrm{b}}$ \\
& Residual & 5747434660,065 & 57 & 100832187,019 & & \\
& 7881328248,333 & 59 & & & \\
\hline
\end{tabular}

a. Dependent Variable: y

b. Predictors: (Constant), X2, X1

Sumber : hasil Output SPSS 22

Hasil perhitungan uji $F$ menunjukkan bahwa nilai $\mathrm{F}$ hitung dibandingkan dengan $\mathrm{F}$ tabel menunjukkan bahwa $\mathrm{F}$ hitung lebih besa dari $\mathrm{F}$ tabel dan nilai probabilitas lebih kecil dari nilai alpha 0,05. Dengan demikian faktor model bisa digunakan dalam penelitian ini.

\subsubsection{Pengujian Hipotesis}


Pengaruh struktur kepemilikan keluarga terhadap nilai perusahaan

Berdasarkan tabel 8 uji t diperoleh hasil bahwa kepemilikan keluarga memiliki nilai signifikan 0,029. Nilai signifikan tersebut lebih kecil dari 0,05. Hal ini menunjukkan bahwa kepemilikan keluarga berpengaruh positif secara signifikan terhadap nilai perusahaan. Hal ini menunjukkan bahwa dengan kepemilikan saham oleh keluarga akan meningkatkan nilai perusahaan karena dengan adanya keluarga yang mendominasi kepemilikan perusahaan akan meningkatkan kepengawasan terhadap manajemen serta pengambilan keputusan yang tepat untuk keberlangsungan hidup perusahaan. Hal ini juga disebabkan karena keluarga memiliki motivasi lebih besar terkait nilai perusahaan yang berafiliasi dengan kekayaan keluarga.

\section{Simpulan dan Saran}

Simpulan

Berdasarkan hasil statistik dan analisis pembahasan maka dapat ditarik kesimpulan sebagai berikut :

1. Kepemilikan keluarga berpengaruh positif signifikan terhadap nilai perusahaan. Hal ini menujukkan bahwa keluarga mampu meningkatkan pengawasan dan mengambil keputusan yang tepat untuk

Saran

Peneliti selanjutnya diharapkan menggunakan variabel lain dari mekanisme internal dari corporate governance selain struktur kepemilikan dan menggunakan variabel eksternal dari corporate governance serta mengambil sampel selain dari perusahaan dengan indeks LQ 45. 4.2 Implikasi Penelitian
4.1.4.1 Pengaruh efektivitas dewan komisaris terhadap nilai perusahaan

Berdasarkan tabel 8 uji t diperoleh hasil bahwa efektivitas dewan komisaris memiliki nilai signifikan 0,003 . Nilai signifikan tersebut lebih kecil dibandingkan nilai alpha 0,05 . Hal ini menunjukkan bahwa efektivitas dewan komisaris berpengaruh positif dan signifikan terhadap nilai perusahaan. Hal ini menunjukkan bahwa efektivitas dewan komisaris memiliki peran penting dalam mengintervensi keputusan manajemen. Dewan komisaris adalah inti dari corporate governance yang bertugas untuk mengawasi manajemen dalam mengelola perusahaan. Sehingga dewan komisaris yang efektif akan mampu melakukan pengawasan terhadap manajemen dan memastikan terciptanya akuntabilitas dalam perusahaan.

meningkatkan nilai perusahan serta keberlangsungan hidup perusahaan.

2. Efektivitas dewan komisaris berpengaruh positif dan signifikan terhadap nilai perusahaan. Hal ini menunjukkan bahwa dewan komisaris sebagai inti dari corporate governance mampumenciptakan akuntabilitas perusahaan.

Hasil penelitian telah menunjukkan bahwa struktur kepemilikan yang direfleksikan oleh kepemilikan keluarga dan struktur pengelolaan perusahaan yang direfleksikan oleh efektivitas dewan komisaris mampu meningkatkan nilai perusahaan yang direfleksikan oleh harga saham penutupan per 31 desember pada perusahaan-perusahaan LQ 45 yang terdaftar dibursa efek 
Indonesia tahun2012-2013. Hasil penelitian ini dapat membantu perusahaan-perusahaan LQ 45 dalam

\section{DAFTAR PUSTAKA}

Arifin, Z. 2003. Masalah agensi dan mekanisme kontrol pada perusahaan dengan struktur kepemilikan terkonsentrasi yang dikontrol keluarga : bukti dari perusahaan publik indonesia diajukan oleh Zaenal Arifin. Disertasi fakultas ekonomi universitas Indonesia

Bukhori, Iqbal \& Raharja. 2012. Pengaruh Good Corporate Governance dan Ukuran PerusahaanTerhadap Kinerja Perusahaan (Studi Empiris pada Perusahaan yang Terdaftar di BEI 2010). Diponegoro Journal of Accounting.

Claessens, $\quad$ S., $\quad$ Djankov.S.,\& Lang,L.H.2000. the separation of ownershipand control in east asian corporations. Journal of financial economics 58,81-112

Debby et al. 2014. Good Corporate Governance, company's characteristic and firm value: emperical study of listing banking on indonesia stock exchange. GSTF Journal on bussiness review (GBR) 3 (4):81-88

Fitri, Dian Oriana. 2012. Analisis pengaruh kepemilikan keluarga terhadap tingkat pengungkapan sukarela dengan efektivitas dewan komisaris sebagai variabel moderasi. Depok. Skripsi Fakultas ekonomi Universitas Indonesia.

Hermawan, A.A. 2009. Pengaruh efektivitas dewan komisaris dan membuat keputusan terkait struktur kepemilikan dan struktur pengelolaan.

komite audit, kepemilikan oleh keluarga dan peran monitoring bank terhadap kandungan informasi laba. Depok. Disertasi fakultas ekonomi universitas Indonesia

Husnan, Suad. 2006. Dasar-Dasar Manajemen Keuangan. Edisi Kelima. Yogyakarta:Unit Penerbitan dan Percetakan STIMYKPN

Ghozali, Imam \& Latan, Hengky. 2012. Partial Least Squares: Konsep, Teknik dan Aplikasi menggunakan Program SmartPLS 3.0 untuk Penelitian Empiris. Edisi 2. Semarang: Undip.

Indeks LQ $45 . \quad$ Melalui http://www.duniainvestasi.com [2/2/17]

Jensen. M. C and Meckling, W.H. 1976. Theory of the Firm: Managerial Behavior Agency Costs and Ownership Structure. Journal of Financial Economics, 3: 305-360.

Mahendra, Alfredo. 2011. Pengaruh Kinerja Keuangan terhadap Nilai Perusahaan(KebijakanDividenseb agaiVariabelModerating)padaPer usahaanManufakturdiBursaEfekI ndonesia.Tesis.ProgramPascasarja na Universitas Udayana.

Monks, R.AG, dan Minow, N.2004. corporate Governance, $3 \mathrm{rd}$ edition.Cambridge.U.K.Blackwell

$\begin{array}{ccc}\text { Khairiyani.2016. } & \text { Pengaruh } & \text { struktur } \\ \text { kepemilakan } & \text { dan } & \text { struktur } \\ \text { pengelolaan } & \text { terhadap } & \text { kinerja }\end{array}$ 
keuangan serta implikasinya terhadap nilai perusahaan pada perusahaan $L Q 45$ di bursa efek indonesia tahun2012-2014. Lampung. SNA

Shleifer A dan Vishny, R. 1997.Asurvey of corporate governance.Journal of finance,vol 52,no 4,pp.737-783

Wang, Neng et al. 2011. A unified Theory of Tobin'sQ, Corporate Investment, Financing and Risk Management. The Journal of Finance vol LXVI no.5 October 2011, pp : 1545-1577 http://www.mit.edu/ huichen/cash. pdf 